\title{
1 Barrier mitigation measures trigger the rapid recovery of genetic connectivity in
}

\section{2 five freshwater fish species}

3 Jérôme G. PRUNIER ${ }^{1 *}$, Géraldine LOOT ${ }^{2}$, Charlotte VEYSSIERE ${ }^{2}$, Nicolas POULET ${ }^{3}$, Simon BLANCHET ${ }^{1,2 *}$

$5 \quad{ }^{1}$ Centre National de la Recherche Scientifique (CNRS), Université Paul Sabatier (UPS), UPR 2001, Station

6 d’Ecologie Théorique et Expérimentale, Moulis, France

$7 \quad{ }^{2}$ CNRS, UPS, UMR 5174 EDB (Laboratoire Évolution \& Diversité Biologique), École Nationale de

8 Formation Agronomique (ENFA), Toulouse Cedex 4, France

$9 \quad{ }^{3}$ DRAS, Pôle R\&D écohydraulique OFBIMFT-PPRIME, Office Français de la Biodiversité, Toulouse, France

* Corresponding authors:

11 Jérôme G. Prunier, Centre National de la Recherche Scientifique (CNRS), UPR 2001, Station d’Ecologie

12 Théorique et Expérimentale, 2 route du CNRS, 09200 Moulis, France ; Email :

13 jerome.prunier@gmail.com; Tel : +33671640804

14 Simon Blanchet, Centre National de la Recherche Scientifique (CNRS), UPR 2001, Station d'Ecologie

15 Théorique et Expérimentale, 2 route du CNRS, 09200 Moulis, France ; Email :

16 simon.blanchet@sete.cnrs.fr 
20

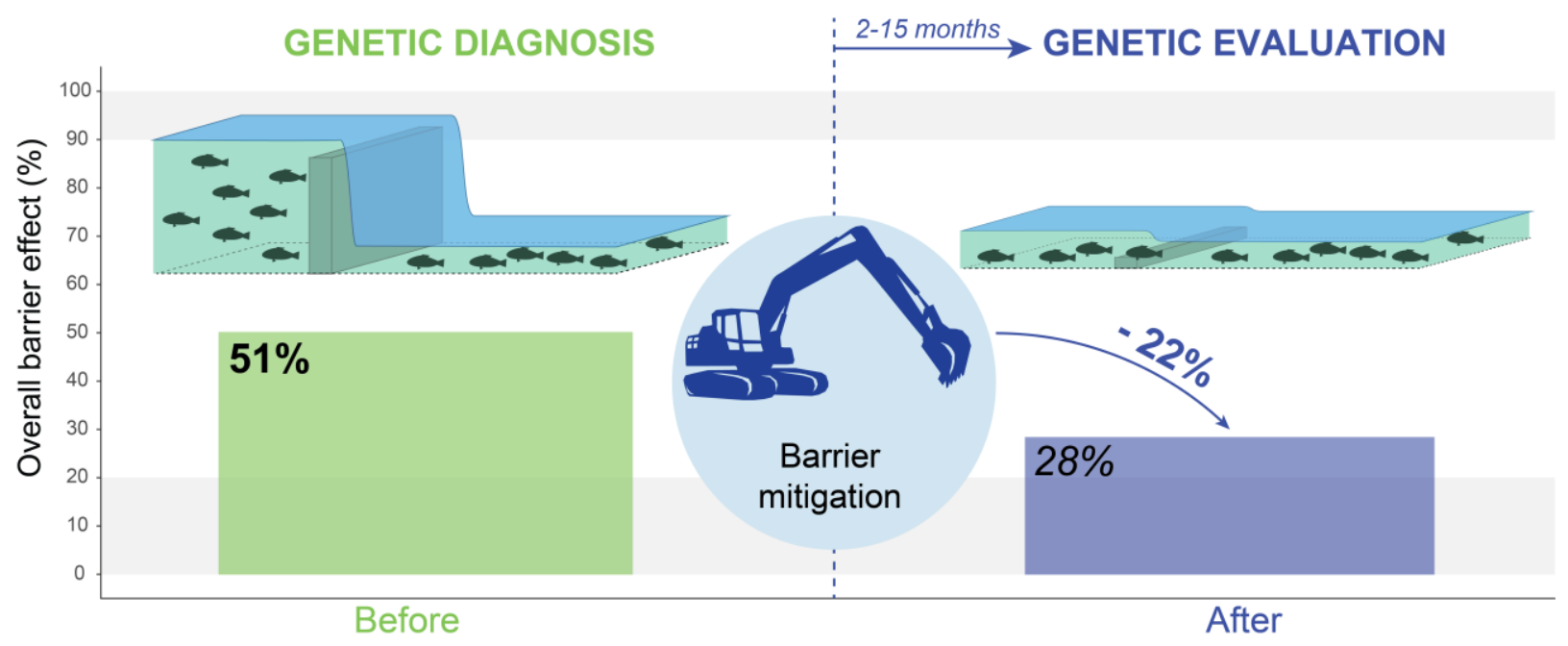

21

Rivers are heavily fragmented by man-made instream barriers such as dams and weirs. This hyperworldwide to mitigate these impacts. However, there is surprisingly little feedback on the efficiency of barrier mitigation measures in restoring riverine connectivity, notably for non-migratory fish species.

27 Here, we implemented a "before-after genetic monitoring" of the restoration of 11 weirs in France using a dedicated genetic index of fragmentation (the $F_{\text {INDEX }}$ ), with a focus on five fish species from two genera.

29 We found that most obstacles actually had a significant impact on connectivity before restoration, especially the highest and steepest ones, with an overall barrier effect of about $51 \%$ of the maximal

31 theoretical impact. Most importantly, we demonstrated for the first time that mitigation measures such

32 as dam removal or fish pass creation significantly and rapidly improved connectivity, with -for some barriers- a complete recovery of the genetic connectivity in less than twelve months. Our study provides 
bioRxiv preprint doi: https://doi.org/10.1101/2021.12.05.471259; this version posted December 6, 2021. The copyright holder for this preprint

(which was not certified by peer review) is the author/funder, who has granted bioRxiv a license to display the preprint in perpetuity. It is made available under aCC-BY-NC-ND 4.0 International license.

35 connectivity and that molecular tools can provide accurate measures of restoration efficiency within a

36 few months.

37 Keywords: Genetic monitoring; Restoration; Weirs; Low-head dams; FINDEX; Fish passes; Dam removal;

38 Genetic connectivity; Potamodromous 


\section{INTRODUCTION}

Anthropogenic activities exert strong pressures on natural ecosystems, which alter both their physical and biological properties (Crutzen, 2006). This is especially the case for rivers that are highly fragmented by man-made instream barriers such as dams, weirs, water mills, etc. (Grill et al., 2019). In Europe for instance, more than one million obstacles have been reported (Belletti et al., 2020), representing 0,74 barriers per kilometer. Riverscape fragmentation affects the quality, the quantity and the accessibility of natural habitats, and thus prevents organisms to fulfill their life-cycle (Taylor et al., 1993). It is considered one of the most important threat to freshwater biodiversity (Sala, 2000). Given this "hyper-fragmentation" of rivers, the restoration of longitudinal (i.e., upstream-downstream) connectivity to promote fluxes of individuals and genes is hence considered a crucial step to recover the integrity of river ecosystems (Baguette et al., 2013; King \& O'Hanley, 2016). Connectivity restoration is moreover the subject of restrictive legislations in many countries, such as in Europe with the Water Framework Directive (2000/60/EC), on which is based the EU's biodiversity strategy for 2030 aiming at restoring at least $25,000 \mathrm{~km}$ of rivers to a free-flowing state (COM/2020/380).

The restoration of longitudinal connectivity implies barrier mitigation measures: the removal of obstacles, or, when removal is not an option (Blanchet \& Tedesco, 2021; Lejon et al., 2009; Magilligan et al., 2017), the equipment of obstacles with natural or artificial fish passes (Seliger \& Zeiringer, 2018; Silva et al., 2018). However, the actual efficiency of these barrier mitigation measures to restore genetic and/or demographic connectivity (Lowe \& Allendorf, 2010) appear somehow unpredictable, depending on the type of river, the type of obstacle, the chosen type of restoration, as well as the timescale and the species considered (Rodeles et al., 2020). Dam removal has been found beneficial for the rapid recovery of some diadromous fish species (mainly salmonids) whose upstream migratory movements

61 and thus spatial distribution were limited by the presence of barriers (Ding et al., 2019). However other 
62

63

64

organisms such as potamodromous fish (but also macroinvertebrates, macrophytes, etc.) may not (immediately) benefit from such removal (Brenkman et al., 2019; Gillette et al., 2016). Similarly, fish passes often show uneven levels of permeability across species, depending on pass design and maintenance as well as environmental conditions (Birnie-Gauvin et al., 2019; Harris et al., 2017; Noonan et al., 2012). These effects are yet still poorly documented, notably in the case of low-head structures (weirs, water-mills, sluices...) that do not benefit from the same attractivity as large dams in terms of public interest and research funding (O'Connor et al., 2015). Low-head structures are actually largely understudied when compared to their prevalence and the restoration efforts they represent (Belletti et al., 2020; Ryan Bellmore et al., 2017). Classical methods for the assessment of connectivity restoration efficiency, such as capture-mark-recapture, telemetry and monitoring of spatiotemporal changes in the composition of fish communities (Rodeles et al., 2020; Silva et al., 2018), cannot be systematically deployed at large management scales, especially for practitioners who are generally constrained by time and budget. For low-head barriers, mitigation measures are often undertaken opportunistically (Poff et al., 2003; Tonitto \& Riha, 2016), with limited or coarse ecological monitoring of the system before restoration (Barry et al., 2018) and no (or limited) evaluation of the outcome in most cases (Cooke et al., 2019; Rodeles et al., 2017).

One challenge for practitioners is notably the lack of rapid and efficient connectivity assessment tools allowing both the a priori quantification of the individual impact of instream obstacles and the $a$ posteriori quantification of the efficiency of implemented measures (removal or equipment; Cooke et al., 2019). If molecular tools are now commonly considered for the a priori assessment of barrier effects (Abernethy et al., 2013; Coleman et al., 2018; Dehais et al., 2010; Gouskov et al., 2016; Liu et al., 2020; Meldgaard et al., 2003; Prunier et al., 2018; Raeymaekers et al., 2009), there is still a surprising paucity of genetic studies dedicated to the temporal monitoring of changes in connectivity after restoration (Ding et al., 2019). Only a handful of recent studies could be identified, all focusing on the 
86 effect of the creation (Liu et al., 2020; Vega-Retter et al., 2020) or the removal (Fraik et al., 2021) of

87 large dams on gene flow (but see Weigel et al., 2013). As a result, and despite the importance for practitioners and managers to assess (and communicate) the relevance of their actions for natural ecosystems, there are still very few indications that (i) current mitigation measures (barrier removal or

90 fish pass creation) deployed worldwide are improving genetic connectivity (sensu Lowe \& Allendorf,

91 2010) and (ii) that molecular approaches are efficient and operational tools to prioritize local restoration

92 actions and assess their efficiency.

94 in France using a recently developed genetic index of fragmentation (the FINDEx; Prunier et al., 2020). The

95 FINDEx provides, independently for each obstacle, an absolute and standardized estimate of (speciesspecific) genetic connectivity, while taking into account two confounding factors: the age of the obstacle

97 and the size of populations on either side of the obstacle. Considering two common potamodromous

98 fish genera, our objectives were (i) to quantify the initial impact of obstacles and thus to determine

99 whether restoration was actually needed in the first place, and (ii) to quantify the gain in connectivity resulting from implemented restoration actions. 


\section{MATERIALS AND METHODS}

\subsection{Instream obstacles}

The study took place at the scale of the French national hydrographic network. In close

coordination with the French Office for Biodiversity (OFB) and French Water Agencies, we identified 11 obstacles (low-head dams $<4 \mathrm{~m}$ high) whose restoration was scheduled for the coming years (Figure 1; and cadastral plans), completed by surveys of local agencies, we estimated that they were constructed

110 (or reconstructed after destruction or abandonment) between the $15^{\text {th }}$ and the $20^{\text {th }}$ century (Table 1 ).

111 The obstacles ranged from 0.8 to $3.5 \mathrm{~m}$ high and showed various slopes (Figure 1). Two of them were

112 already equipped with a fish pass (Table 1$)$. Each obstacle was described according to its height $(<$ or $\geq$

$1132 \mathrm{~m}$ high) and slope (< or $\geq 45^{\circ}$ ) using a unique synthetic factor 'Typology' with four levels ('low and

114 gentle', 'low and steep', 'high and gentle', 'high and steep'). The restoration actions were conducted

115 between 2015 and 2019 and in most cases (9 out of 11) consisted in the dismantlement of the obstacle.

116 Note that we could not statistically assess the specific effects of fish passes on connectivity in the 117 following analyses because there were too few of them, either before or after restoration.

\subsection{Biological models and Before-After sampling sessions}

We focused on five common potamodromous species from two genera: minnows (Phoxinus sp.: $P$.

121 phoxinus in the Seine, P. fayollarum in the Loire and P. dragarum in the Garonne watershed) and

122 gudgeons (Gobio sp: G. gobio in the Loire and the Seine and G. occitaniae in the Garonne watershed).

123 Within each genus, species are allopatric (Denys et al., 2020) but were here considered to have very

124 similar life history traits and movement behaviors (Keith et al., 2011). These species are small

125 insectivorous cyprinids (maximal body length of 140 and $200 \mathrm{~mm}$, in minnows and gudgeons 
respectively) that show distinct foraging strategies: minnows preferentially feeds in the water column,

127 whereas gudgeons feed on the bottom (Keith et al., 2011). We selected these species because they are widespread and abundant and hence easy to catch for practitioners, which make them ideal models for an operational tool such as the $\mathrm{F}_{\text {INDEX. }}$

Sampling operations 'Before' and 'After' restoration were performed using electrofishing, until a maximum of 30 adult individuals of each species were captured on either side of obstacles. Fish were and permits.

Both genera could be sampled at all sites except in DADRai (gudgeons only) and GLASou (minnows

\subsection{Genotyping and FINDEX computation}

We considered 19 and 15 microsatellite markers in minnows and gudgeons, respectively. DNA extraction, genotyping and assessment of null alleles and gametic disequilibrium followed previously published procedures (Prunier et al., 2018, 2020; Appendix S1). For each dataset (combination of one

147 obstacle and one genus; $\mathrm{n}=20$ since only one genus could be sampled at GLASou and DADRai; Table 2) and each passage ('Before' and 'After'), we computed the FINDEX and the standard deviation of the FINDEX 
the rescaling of pairwise measures of genetic differentiation within their theoretical range of variation given effective population sizes (approximated from expected heterozygosity) and the number of

152 generations elapsed since barrier creation. The FINDEX $_{\text {is }}$ therefore a standardized (across barriers and

153 species) index expressed as a percentage, with values lower than $20 \%$ representing fully permeable

154 structures and values higher than 90\% representing total barriers to gene flow (see Prunier et al., 2020

155 for details). FINDEX values are computed along with a standard deviation $\mathrm{SD}_{\mathrm{F}}$ (or a $95 \%$ confidence interval

$156 \mathrm{Cl}_{95 \%}$ ) that takes into account biological uncertainty stemming from $\mathrm{n}_{\mathrm{F}}=4$ parameters (two mutation

157 rates and two metrics of genetic differentiation; Prunier et al., 2020). We considered a generation time 158 of 2 years in minnows and 2.5 years in gudgeons to compute the number of generations elapsed since 159 barrier creation (Kottelat \& Freyhof, 2007).

We adopted a meta-analytical approach (Borenstein, 2009), considering each dataset

163 (combination of one obstacle and one genus; $\mathrm{n}=20$ ) as an independent study providing two effect sizes

$164\left(F_{\text {INDEX }}\right.$ values before and after restoration $\left.\pm S D_{F}\right)$. Six datasets were non-informative $\left(F_{\text {INDEX }}=0\right.$ and $S D_{F}=$ 1650 before restoration) and were thus discarded, resulting in 14 datasets, of which three were associated 166 with a non-significant barrier effect (see results). The interpretation of the $\mathrm{F}_{\text {INDEx }}$ being meaningful

167 (barrier effect expressed as a percentage of maximum fragmentation), the FINDEx value before

168 restoration was directly used as the observed effect size $\mathrm{F} \pm \mathrm{SE}_{\mathrm{F}}$ of barrier effect in each dataset, with

$169 S E_{F}=S D_{F} / \sqrt{n_{F}}$. We used the raw difference $\Delta \mathrm{F}\left( \pm \mathrm{SE} \mathrm{E}_{\Delta}\right)$ between FINDEX values computed after

170 ('treatment') and before ('control') restoration as the observed effect size of restoration for each

171 dataset (Equations 4.2 and 4.6 in Borenstein, 2009). The raw difference $\Delta \mathrm{F}$ can be directly interpreted as 
172 the (positive or negative) change in the amount of fragmentation following restoration and was thus

173 preferred over the standardized mean difference Hedges' g (Borenstein, 2009).

We used random-effect meta-regressions with moderators (metafor::rma.mv R-function; Harrer

175 et al., 2021; Viechtbauer, 2010) to compute the overall true effect sizes of the barrier effects $\bar{F}$ and of

176 the restoration of obstacles $\overline{\Delta F}(\mathrm{n}=14)$, while taking into account different possible sources of variation

177 in effect sizes: within-datasets (i.e., $\mathrm{SE}_{\mathrm{F}}$ or $\mathrm{SE}_{\Delta}$ ), between-datasets and, possibly, across different

178 covariate modalities. Considered covariates were 'Genus' (two levels: minnows or gudgeons), 'Typology'

179 (four levels: see above), as well as, in the case of $\overline{\Delta F}$, the 'timelag' (two levels: $<1$ year or $>1$ year)

180 between the restoration operation and the second sampling session. To account for within-dataset

181 variability $\left(\mathrm{SE}_{\mathrm{F}}\right.$ or $\mathrm{SE}_{\Delta}$ ), we used dataset ID as an outer random grouping factor. To allow residual

182 heterogeneity to differ across covariate modalities, each covariate was successively defined both as a

183 moderator and an inner random grouping factor. Models were run with a diagonal variance-covariance

184 matrix as a random effect structure. Covariates identified as significant moderators were then kept as

185 inner random grouping factors in final models without moderator to get final estimates of the true

186 effect sizes $\bar{F}$ and $\overline{\Delta F}$ along with their respective $95 \%$ confidence interval $\mathrm{Cl}_{95 \% \text {. }}$ 


\section{RESULTS}

Altogether, a total of 1049 and 1038 genotypes could be obtained from the various sampling sessions (through space and time) in minnows and in gudgeons, respectively, with an overall mean of 26.1 ( $\pm 3.2 \mathrm{SD}$ ) genotypes per genus, sampling site and sampling session. The mean number of loci across datasets was $15.7( \pm 1.8 \mathrm{SD})$ and $14.4( \pm 0.8 \mathrm{SD})$ in minnows and in gudgeons, respectively. barrier effect detected in 11 out of 20 datasets (Table 2). Genera showed highly contrasted responses to obstacles: all obstacles but GLAMou and LEZVil had a significant impact on connectivity before restoration, but only VIAPig and GLAPas did impact both genera simultaneously (Table 2; Figure 2).

Accordingly, 'Genus' was not identified as a significant moderator of the overall effect size $\bar{F}$ (Table 3). 57.7]). had no effect either ( $F_{\text {INDEX }}<20 \%$ after restoration; 5/10 obstacles in gudgeons and 4/10 obstacles in minnows), restoration systematically led to a significant decrease in FINDEX values (as indicated by non-

207 (mean: $13.7 \pm 17.8$ SD). This decrease led to the full recovery of connectivity $\left(F_{\text {INDEX }}<20 \%\right.$ after restoration) in $3 / 5$ obstacles in gudgeons and $2 / 6$ obstacles in minnows. The observed effect sizes of 
210 or 'Timelag' were identified as significant moderators of the overall effect size of restoration $\overline{\Delta F}$ (Table

2113 , Appendix S2). The final overall effect size of restoration $\overline{\Delta F}$ was of $-21.7 \%$, a value significantly

212 different from $0\left(\mathrm{Cl}_{95 \%}=[-30.2 ;-13.2]\right)$. Overall, the effect of restoration was thus the same across

213 genera, did not depend on the typology of the obstacle and, interestingly, was independent from the

214 timelag between the restoration and the second sampling session. In other words, we found evidence

215 that genetic connectivity could be recovered (entirely in some cases, partly in most cases) in just a few

216 months after restoration. 


\section{DISCUSSION}

Quantifying the impact of instream barriers on potamodromous fish species as well as the

221 efficiency of mitigation measures is primordial in the context of restoration planning, so as to properly

222 allocate limited resources towards the most impactful obstacles, inform trade-offs between ecological

223 and socio-economic issues, and refine restoration techniques (Hermoso et al., 2012; Rodeles et al.,

224 2020; Silva et al., 2018). Quantification is yet a difficult task, notably because of technical and financial

225 constraints preventing the parallel monitoring of multiple obstacles and because of the relative lack of

226 operational tools allowing valid comparisons across both contexts and species (Cayuela et al., 2018). The

227 response of freshwater organisms to connectivity restoration has often been studied at the community-

228 or at the population-levels (Brenkman et al., 2019; Frey, 2021; Magilligan et al., 2021; Muha et al., 2021;

229 Stanley et al., 2002; Sun et al., 2021), rarely at the genetic level (Fraik et al., 2021), and our study is the

230 first to document the systematic and rapid recovery of gene flow over a series of independent

231 restoration actions. In this study, we used a standardized genetic index of fragmentation to quantify

232 both the impact of 11 low-head dams on gene flow in five freshwater fish species, and the efficiency of

233 mitigation actions in restoring genetic connectivity.

Before restoration, we found a significant barrier effect in 11 out of 20 datasets, with two

235 obstacles showing no impact on any genus and two obstacles significantly impacting both genera.

236 Surprisingly, out of nine obstacles with genetic data in both genera, five showed large discrepancies in

237 genus response to fragmentation, with either only gudgeons or only minnows significantly impacted

238 (Figure 2). These discrepancies illustrate how barrier effects can be highly species- or genus-dependent

239 (Amaral et al., 2021; Blanchet et al., 2010; Prunier et al., 2018), and thus hardly predictable given our

240 limited knowledge about fish movement behavior and capacities (Baudoin et al., 2014; Thurow, 2016).

241 In absence of a dedicated fish pass, individuals are supposed to take advantage of drowned conditions, 
242 that is, of periods where water level rises above the height of the dam, to cross the obstacle (Keller et

243 al., 2012). However, such propitious conditions of obstacle drowning might not be encountered every

244 year, at all localities, and equally across all species/individuals, depending on their swimming behavior

245 and capabilities in various environmental conditions and to the timing of submersion compared with the

246 timing of individual movements (Carpenter-Bundhoo et al., 2020; Holthe et al., 2005; Keller et al., 2012).

247 This may explain why FINDEx values differed so much across datasets, and why the overall effect size of

248 fragmentation $\bar{F}$ was unrelated to the considered genus. However, $\bar{F}$ was significantly influenced by the

249 typology of obstacles, with high and steep obstacles showing an overall effect size $\bar{F} 40 \%$ higher than

250 low and gentle obstacles (Table 3, Figure 3). This finding is in line with classical expectations about the

251 impact of dam typology (e.g., Januchowski-Hartley et al., 2019) and conclusions from other studies (e.g.,

252 Amaral et al., 2019; Keller et al., 2012; Zigler et al., 2004), as well as with the obstacle drowning

253 hypothesis: the highest dams ( $\geq 2 \mathrm{~m}$ ) might rarely be drowned (leading to the increase in $\bar{F}$ ), but, in

254 presence of a gentle slope $\left(<45^{\circ}\right)$, they might become partly crossable by some individuals, at least at

255 intermediate drowning conditions, so that only the highest and steepest obstacles have an overall

256 significant effect size $(\bar{F}=54.6 \%$; Figure 3$)$. This result should of course be confirmed and refined with

257 additional datasets, but it provides a relevant and meaningful benchmark for practitioners to adjust

258 restoration planning even in the absence of any individual quantification of barrier effects.

With this effect of typology taken into account, we estimated the true effect size of fragmentation

260 as of $\bar{F}=51.4 \%$ : in other words, we might expect a $51 \%$ decrease in gene flow in presence of a low-

261 head dam (irrespective of the species or the context). Given these different findings, it appears that a

262 preliminary diagnosis based on a standardized genetic tool such as the FINDEx may actually help managers

263 quantify and compare barrier effects across species and obstacles, and thus orientate their restoration

264 efforts towards the most problematic structures (Prunier et al., 2020), keeping in mind that the most

265 impactful obstacles might be the highest and steepest ones, but that more seemingly anodyne obstacles 
might also be particularly impacting for some species. Of course, we willingly acknowledge that other ecological and socio-economic indicators should be considered in restoration planning as well (Hermoso et al., 2012). It is also noteworthy that the $F_{\text {INDEX }}$ might help evaluate the species-specific efficiency of fish passes, an important step to drive future technical developments (Foulds \& Lucas, 2013): the two considered fish passes before restoration appeared beneficial in all situations except for minnows at

271 SIOBre (Figure 2), illustrating the challenge of locally designing passes adapted to different fish species

272 with distinct life-history traits and requirements (Birnie-Gauvin et al., 2019; Silva et al., 2018). to a significant reduction of barrier effects, provided there was an actual barrier effect in the first place.

275 We quantified an overall $22 \%$ decrease in fragmentation levels following restoration. This means that 276 mitigation measures may allow the full recovery of genetic connectivity for any initial fragmentation 277 level of up to $42 \%$ (i.e., $20 \%<\mathrm{F}_{\text {INDEX }} \leq 42 \%$ ), a value to be compared to the overall effect size of

278 fragmentation $\bar{F}=51 \%$ before restoration. Most interestingly, this systematic gain in connectivity was 279 achieved within a few months after restoration only. For instance, weir removal led to the full recovery of genetic connectivity at three localities (LEZCas, VIAPig and GLAPas), indicating that it ensured the full

281 mixing of individuals, and thus of allelic frequencies, within a year, and even within two months only at 282 VIAPig. However, not all restoration actions proved equally efficient within the same timeframe, the 283 recovery of connectivity being only partial in several situations. This is the case of the two (new or 284 improved) fish passes at SERHau and SIOBre that resulted in an 8 to $12 \%$ recovery in genetic connectivity 285 in minnows within a year. These reductions are highly encouraging, but it is still unknown whether recovery is still ongoing: further temporal monitoring is needed to detect migration-drift equilibrium

287 and determine the final gain in connectivity following restoration. Furthermore, and although weir 288 removal is expected to be more efficient than fish pass creation as a restoration option (Birnie-Gauvin et 
sometimes even after a year (e.g., at CEOSal in minnows). The migration behavior of fish being still

291 poorly documented and likely to deeply differ across species and contexts, it probably explains why the

292 true effect size of restoration was unrelated to the considered genus, the typology of the obstacle or the

293 timelag between restoration and sampling. We can only speculate on why close-range genetic mixing

294 would sometimes take so long despite the absence of any obstacle to movement. For instance, weir

295 removal might result in profound changes in upstream and downstream habitat characteristics

296 (Bednarek, 2001; Doyle et al., 2005), locally inducing a temporary repelling effect on fish. It has also

297 been suggested that, in some conditions, fragmentation might lead individuals to adjust their life-history

298 strategies towards residency (Branco et al., 2017), which might further delay genetic connectivity after

299 removal. Nevertheless, we expect the full recovery of genetic connectivity in the coming years, which

300 will however require further genetic monitoring of these situations. 


\section{CONCLUSION}

Our study provides a strong proof-of-concept that barrier removal and, probably to a lesser extent, fish pass creation, are efficient mitigation strategies to restore riverine genetic connectivity in just a few months. We also illustrated how before-after genetic monitoring based on a standardized tool such as the FINDEX constitute a promising support for practitioners in the planning and the monitoring of

307 restoration. We believe that the large-scale deployment of this methodology in the future, with a 308 growing number of case studies, will make it possible to lift the veil on the complex links between 309 individual crossing success, life history traits of organisms and barrier typologies.

\section{ACKNOWLEDGEMENTS}

312 This study was financially supported by the Office Français pour la Biodiversité and the Région Occitanie.

313 We warmly thank all the members of local agencies (Office Français pour la Biodiversité, Fédérations de

314 Pêche, Syndicats Mixtes, Agences de l'Eau) that have been involved in this project and directly helped us

315 fulfill our objectives, either by performing the sampling or by providing valuable information about local 316 restoration actions.

319 JGP, SB and NP conceived the ideas and designed methodology; JGP and SB collected the samples in the 320 field; CV and GL produced molecular data; JGP analyzed the data; JGP and SB led the writing of the 321 manuscript. All authors contributed critically to the drafts and gave final approval for publication. 
Abernethy, E., McCombs, E., Siefferman, L., \& Gangloff, M. (2013). Effect of Small Dams on Freshwater Mussel Population Genetics in Two Southeastern Usa Streams. Freshwater Mollusk Biology and Conservation, 16(1), 21. https://doi.org/10.31931/fmbc.v16i1.2013.21-28

Adamack, A. T., \& Gruber, B. (2014). POPGENREPORT: Simplifying basic population genetic analyses in R. Methods in Ecology and Evolution, 5(4), 384-387. https://doi.org/10.1111/2041-210X.12158

Aljanabi, S. M., \& Martinez, I. (1997). Universal and rapid salt-extraction of high quality genomic DNA for PCR-based techniques. Nucleic Acids Research, 25(22), 4692-4693.

Amaral, S. D., Branco, P., Katopodis, C., Ferreira, M. T., Pinheiro, A. N., \& Santos, J. M. (2019). Passage Performance of Potamodromous Cyprinids over an Experimental Low-Head Ramped Weir: The Effect of Ramp Length and Slope. Sustainability, 11(5), 1456. https://doi.org/10.3390/su11051456

Amaral, S. D., Branco, P., Romão, F., Ferreira, M. T., Pinheiro, A. N., \& Santos, J. M. (2021). Evaluation of Low-Head Ramped Weirs for a Potamodromous Cyprinid: Effects of Substrate Addition and Discharge on Fish Passage Performance, Stress and Fatigue. Water, 13(6), 765. https://doi.org/10.3390/w13060765

Baguette, M., Blanchet, S., Legrand, D., Stevens, V. M., \& Turlure, C. (2013). Individual dispersal, landscape connectivity and ecological networks: Dispersal, connectivity and networks. Biological Reviews, 88(2), 310-326. https://doi.org/10.1111/brv.12000

Barry, J., Coghlan, B., Cullagh, A., Kerr, J. R., \& King, J. J. (2018). Comparison of coarse-resolution rapid methods for assessing fish passage at riverine barriers: ICE and SNIFFER protocols: Protocol comparison of fish passability at barriers. River Research and Applications, 34(9), 1168-1178. https://doi.org/10.1002/rra.3358 
Baudoin, J.-M., Burgun, V., Chanseau, M., Larinier, M., Ovidio, M., Sremski, W., Steinbach, P., \& Voegtle, B. (2014). The ICE protocol for ecological continuity, Assessing the passage of obstacles by fish: Concepts, design and application. Onema.

Bednarek, A. T. (2001). Undamming Rivers: A Review of the Ecological Impacts of Dam Removal. Environmental Management, 27(6), 803-814. https://doi.org/10.1007/s002670010189

Belletti, B., Garcia de Leaniz, C., Jones, J., Bizzi, S., Börger, L., Segura, G., Castelletti, A., van de Bund, W., Aarestrup, K., Barry, J., Belka, K., Berkhuysen, A., Birnie-Gauvin, K., Bussettini, M., Carolli, M., Consuegra, S., Dopico, E., Feierfeil, T., Fernández, S., ... Zalewski, M. (2020). More than one million barriers fragment Europe's rivers. Nature, 588(7838), 436-441. https://doi.org/10.1038/s41586-020-3005-2

Birnie-Gauvin, K., Franklin, P., Wilkes, M., \& Aarestrup, K. (2019). Moving beyond fitting fish into equations: Progressing the fish passage debate in the Anthropocene. Aquatic Conservation: Marine and Freshwater Ecosystems, 29(7), 1095-1105. https://doi.org/10.1002/aqc.2946

Blanchet, S., Rey, O., Etienne, R., Lek, S., \& Loot, G. (2010). Species-specific responses to landscape fragmentation: Implications for management strategies. Evolutionary Applications, 3(3), 291304. https://doi.org/10.1111/j.1752-4571.2009.00110.x

Blanchet, S., \& Tedesco, P. A. (2021). French vote for river barriers defies biodiversity strategy. Nature, 594(7861), 26-26. https://doi.org/10.1038/d41586-021-01467-0

Borenstein, M. (Ed.). (2009). Introduction to meta-analysis. John Wiley \& Sons.

Branco, P., Amaral, S. D., Ferreira, M. T., \& Santos, J. M. (2017). Do small barriers affect the movement of freshwater fish by increasing residency? Science of The Total Environment, 581-582, 486-494. https://doi.org/10.1016/j.scitotenv.2016.12.156

Brenkman, S. J., Peters, R. J., Tabor, R. A., Geffre, J. J., \& Sutton, K. T. (2019). Rapid Recolonization and Life History Responses of Bull Trout Following Dam Removal in Washington's Elwha River. North 
American Journal of Fisheries Management, 39(3), 560-573. https://doi.org/10.1002/nafm.10291 Effects of a low-head weir on multi-scaled movement and behavior of three riverine fish species. Scientific Reports, 10(1), 6817. https://doi.org/10.1038/s41598-020-63005-8 Demographic and genetic approaches to study dispersal in wild animal populations: A methodological review. Molecular Ecology, 27(20), 3976-4010. https://doi.org/10.1111/mec.14848

Coleman, R. A., Gauffre, B., Pavlova, A., Beheregaray, L. B., Kearns, J., Lyon, J., Sasaki, M., Leblois, R., Sgro, C., \& Sunnucks, P. (2018). Artificial barriers prevent genetic recovery of small isolated

Cooke, S. J., Bennett, J. R., \& Jones, H. P. (2019). We have a long way to go if we want to realize the promise of the "Decade on Ecosystem Restoration." Conservation Science and Practice, 1(12). https://doi.org/10.1111/csp2.129

Crutzen, P. J. (2006). The “Anthropocene." In E. Ehlers \& T. Krafft (Eds.), Earth System Science in the Anthropocene (pp. 13-18). Springer-Verlag. https://doi.org/10.1007/3-540-26590-2_3 (Cyprinidae: Squalius cephalus) population of the Durance River: estimating fragmentation by dams: Genetic isolation in chub. Ecology of Freshwater Fish, 19(2), 267-278. https://doi.org/10.1111/j.1600-0633.2010.00411.x 
Denys, G. P. J., Dettai, A., Persat, H., Daszkiewicz, P., Hautecœur, M., \& Keith, P. (2020). Revision of Phoxinus in France with the description of two new species (Teleostei, Leuciscidae). https://doi.org/10.26028/CYBIUM/2020-443-003

Ding, L., Chen, L., Ding, C., \& Tao, J. (2019). Global Trends in Dam Removal and Related Research: A Systematic Review Based on Associated Datasets and Bibliometric Analysis. Chinese Geographical Science, 29(1), 1-12. https://doi.org/10.1007/s11769-018-1009-8

Doyle, M. W., Stanley, E. H., Orr, C. H., Selle, A. R., Sethi, S. A., \& Harbor, J. M. (2005). Stream ecosystem response to small dam removal: Lessons from the Heartland. Geomorphology, 71(1-2), 227244. https://doi.org/10.1016/j.geomorph.2004.04.011

Foulds, W. L., \& Lucas, M. C. (2013). Extreme inefficiency of two conventional, technical fishways used

Fraik, A. K., McMillan, J. R., Liermann, M., Bennett, T., McHenry, M. L., McKinney, G. J., Wells, A. H., Winans, G., Kelley, J. L., Pess, G. R., \& Nichols, K. M. (2021). The Impacts of Dam Construction and Removal on the Genetics of Recovering Steelhead (Oncorhynchus mykiss) Populations

Frey, R. (2021). Immediate response of black basses to dam removal is determined by habitat preference. Masters Theses, 4862. https://thekeep.eiu.edu/theses/4862

Gillette, D. P., Daniel, K., \& Redd, C. (2016). Fish and Benthic Macroinvertebrate Assemblage Response to Removal of a Partially Breached Lowhead Dam: Assemblage Response to Lowhead Dam Removal. River Research and Applications, 32(8), 1776-1789. https://doi.org/10.1002/rra.3017

412 Gouskov, A., Reyes, M., Wirthner-Bitterlin, L., \& Vorburger, C. (2016). Fish population genetic structure 
Grenier, R., Costedoat, C., Chappaz, R., \& Dubut, V. (2013). Two multiplexed sets of 21 and 18 microsatellites for Phoxinus phoxinus (L.) and Gobio gobio (L.) developed by cross-species amplification. European Journal of Wildlife Research, 59(2), 291-297. https://doi.org/10.1007/s10344-013-0693-z

Grill, G., Lehner, B., Thieme, M., Geenen, B., Tickner, D., Antonelli, F., Babu, S., Borrelli, P., Cheng, L., Crochetiere, H., Ehalt Macedo, H., Filgueiras, R., Goichot, M., Higgins, J., Hogan, Z., Lip, B., McClain, M. E., Meng, J., Mulligan, M., ... Zarfl, C. (2019). Mapping the world's free-flowing rivers. Nature, 569(7755), 215-221. https://doi.org/10.1038/s41586-019-1111-9

Harrer, M., Cuijpers, P., Furukawa, T. A., \& Ebert, D. D. (2021). Doing meta-analysis with R: A hands-on guide (First edition). CRC Press.

Harris, J. H., Kingsford, R. T., Peirson, W., \& Baumgartner, L. J. (2017). Mitigating the effects of barriers to freshwater fish migrations: The Australian experience. Marine and Freshwater Research, 68(4), 614. https://doi.org/10.1071/MF15284

Hermoso, V., Pantus, F., Olley, J., Linke, S., Mugodo, J., \& Lea, P. (2012). Systematic planning for river rehabilitation: Integrating multiple ecological and economic objectives in complex decisions. Freshwater Biology, 57(1), 1-9. https://doi.org/10.1111/j.1365-2427.2011.02693.x

Holthe, E., Lund, E., Finstad, B., Thorstad, E. B., \& McKinley, R. S. (2005). A fish selective obstacle to prevent dispersion of an unwanted fish species, based on leaping capabilities. Fisheries Management and Ecology, 12(2), 143-147.

Januchowski-Hartley, S. R., Jézéquel, C., \& Tedesco, P. A. (2019). Modelling built infrastructure heights to evaluate common assumptions in aquatic conservation. Journal of Environmental Management, 232, 131-137. https://doi.org/10.1016/j.jenvman.2018.11.040

Keith, P., Persat, H., Feunteun, E., Adam, B., \& Geniez, M. (2011). Les Poissons d'eau douce de France (Muséum National d'Histoire Naturelle and Publications Biotope). 
Keller, R. J., Peterken, C. J., \& Berghuis, A. P. (2012). Design and assessment of weirs for fish passage under drowned conditions. Ecological Engineering, 48, 61-69. https://doi.org/10.1016/j.ecoleng.2011.06.037

Kemp, P. S., \& O'Hanley, J. R. (2010). Procedures for evaluating and prioritising the removal of fish passage barriers: A synthesis. Fisheries Management and Ecology, no-no. https://doi.org/10.1111/j.1365-2400.2010.00751.x

King, S., \& O'Hanley, J. R. (2016). Optimal Fish Passage Barrier Removal-Revisited. River Research and Applications, 32(3), 418-428. https://doi.org/10.1002/rra.2859

Kottelat, M., \& Freyhof, J. (2007). Handbook of european freshwater fishes. Publications Kottelat. Lejon, A. G. C., Malm Renöfält, B., \& Nilsson, C. (2009). Conflicts Associated with Dam Removal in Sweden. Ecology and Society, 14(2), art4. https://doi.org/10.5751/ES-02931-140204

Liu, D., Li, X., \& Song, Z. (2020). No decline of genetic diversity in elongate loach (Leptobotia elongata) with a tendency to form population structure in the upper Yangtze River. Global Ecology and Conservation, 23, e01072. https://doi.org/10.1016/j.gecco.2020.e01072

Lowe, W. H., \& Allendorf, F. W. (2010). What can genetics tell us about population connectivity? Molecular Ecology, 19(15), 3038-3051. https://doi.org/10.1111/j.1365-294X.2010.04688.x

Magilligan, F. J., Nislow, K. H., Dietrich, J. T., Doyle, H., \& Kynard, B. (2021). Transient versus sustained biophysical responses to dam removal. Geomorphology, 389, 107836. https://doi.org/10.1016/j.geomorph.2021.107836

Magilligan, F. J., Sneddon, C. S., \& Fox, C. A. (2017). The Social, Historical, and Institutional Contingencies of Dam Removal. Environmental Management, 59(6), 982-994. https://doi.org/10.1007/s00267017-0835-2

Meldgaard, T., Nielsen, E. E., \& Loeschcke, V. (2003). Fragmentation by weirs in a riverine system: A study of genetic variation in time and space among populations of European grayling (Thymallus 
thymallus) in a Danish river system. Conservation Genetics, 4(6), 735-747.

https://doi.org/10.1023/B:COGE.0000006115.14106.de

465

466

Muha, T. P., Rodriguez-Barreto, D., O’Rorke, R., Garcia de Leaniz, C., \& Consuegra, S. (2021). Using eDNA Metabarcoding to Monitor Changes in Fish Community Composition After Barrier Removal. Frontiers in Ecology and Evolution, 9, 629217. https://doi.org/10.3389/fevo.2021.629217

Noonan, M. J., Grant, J. W. A., \& Jackson, C. D. (2012). A quantitative assessment of fish passage efficiency: Effectiveness of fish passage facilities. Fish and Fisheries, 13(4), 450-464. https://doi.org/10.1111/j.1467-2979.2011.00445.x

O'Connor, J. E., Duda, J. J., \& Grant, G. E. (2015). 1000 dams down and counting. Science, 348(6234), 496-497. https://doi.org/10.1126/science.aaa9204

Poff, N. L., Allan, J. D., Palmer, M. A., Hart, D. D., Richter, B. D., Arthington, A. H., Rogers, K. H., Meyer, J. L., \& Stanford, J. A. (2003). River flows and water wars: Emerging science for environmental decision making. Frontiers in Ecology and the Environment, 1(6), 298-306.

Prunier, J. G., Dubut, V., Loot, G., Tudesque, L., \& Blanchet, S. (2018). The relative contribution of river network structure and anthropogenic stressors to spatial patterns of genetic diversity in two freshwater fishes: A multiple-stressors approach. Freshwater Biology, 63(1), 6-21. https://doi.org/10.1111/fwb.13034

Prunier, J. G., Poesy, C., Dubut, V., Veyssière, C., Loot, G., Poulet, N., \& Blanchet, S. (2020). Quantifying the individual impact of artificial barriers in freshwaters: A standardized and absolute genetic index of fragmentation. Evolutionary Applications, eva.13044. https://doi.org/10.1111/eva.13044

Raeymaekers, J. A. M., Raeymaekers, D., Koizumi, I., Geldof, S., \& Volckaert, F. A. M. (2009). Guidelines for restoring connectivity around water mills: A population genetic approach to the 
management of riverine fish. Journal of Applied Ecology, 46(3), 562-571.

https://doi.org/10.1111/j.1365-2664.2009.01652.x

Rodeles, A. A., Galicia, D., \& Miranda, R. (2017). Recommendations for monitoring freshwater fishes in river restoration plans: A wasted opportunity for assessing impact. Aquatic Conservation: Marine and Freshwater Ecosystems, 27(4), 880-885. https://doi.org/10.1002/aqc.2753

Rodeles, A. A., Miranda, R., \& Galicia, D. (2020). Barriers to longitudinal river connectivity: Review of impacts, study methods and management for Iberian fish conservation. Limnetica, 39(2), 1. https://doi.org/10.23818/limn.39.39

Rousset, F. (2008). GENEPOP '007: A complete re-implementation of the GENEPOP software for Windows and Linux. Molecular Ecology Resources, 8(1), 103-106.

Ryan Bellmore, J., Duda, J. J., Craig, L. S., Greene, S. L., Torgersen, C. E., Collins, M. J., \& Vittum, K. (2017). Status and trends of dam removal research in the United States. Wiley Interdisciplinary Reviews: Water, 4(2), e1164. https://doi.org/10.1002/wat2.1164

Sala, O. E. (2000). Global Biodiversity Scenarios for the Year 2100\&amp;nbsp; Science, 287(5459), 17701774. https://doi.org/10.1126/science.287.5459.1770

Seliger, C., \& Zeiringer, B. (2018). River Connectivity, Habitat Fragmentation and Related Restoration Measures. In S. Schmutz \& J. Sendzimir (Eds.), Riverine Ecosystem Management (pp. 171-186). Springer International Publishing. https://doi.org/10.1007/978-3-319-73250-3_9 Pompeu, P. S., O’Brien, G. C., Braun, D. C., Burnett, N. J., Zhu, D. Z., Fjeldstad, H.-P., Forseth, T., Rajaratnam, N., Williams, J. G., \& Cooke, S. J. (2018). The future of fish passage science, engineering, and practice. Fish and Fisheries, 19(2), 340-362. https://doi.org/10.1111/faf.12258 
Stanley, E. H., Luebke, M. A., Doyle, M. W., \& Marshall, D. W. (2002). Short-Term Changes in Channel Form and Macroinvertebrate Communities Following Low-Head Dam Removal. Journal of the North American Benthological Society, 21(1), 172-187. https://doi.org/10.2307/1468307

Sun, J., Galib, S. M., \& Lucas, M. C. (2021). Rapid response of fish and aquatic habitat to removal of a tidal barrier. Aquatic Conservation: Marine and Freshwater Ecosystems, aqc.3576. https://doi.org/10.1002/aqc.3576

Taylor, P. D., Fahrig, L., Henein, K., \& Merriam, G. (1993). Connectivity is a vital element of landscape structure. Oikos, 571-573.

Thurow, R. F. (2016). Life Histories of Potamodromous Fishes. In P. Morais \& F. Daverat (Eds.), An Introduction to Fish Migration (p. 26). CRC Press.

Tonitto, C., \& Riha, S. J. (2016). Planning and implementing small dam removals: Lessons learned from dam removals across the eastern United States. Sustainable Water Resources Management, 2(4), 489-507. https://doi.org/10.1007/s40899-016-0062-7

Vega-Retter, C., Muñoz-Rojas, P., Rojas-Hernández, N., Copaja, S., Flores-Prado, L., \& Véliz, D. (2020). Dammed river: Short- and long-term consequences for fish species inhabiting a river in a Mediterranean climate in central Chile. Aquatic Conservation: Marine and Freshwater Ecosystems, aqc.3425. https://doi.org/10.1002/aqc.3425

Viechtbauer, W. (2010). Conducting Meta-Analyses in $R$ with the metafor Package. Journal of Statistical Software, 36(3). https://doi.org/10.18637/jss.v036.i03

Weigel, D. E., Connolly, P. J., Martens, K. D., \& Powell, M. S. (2013). Colonization of Steelhead in a Natal Stream after Barrier Removal. Transactions of the American Fisheries Society, 142(4), 920-930. https://doi.org/10.1080/00028487.2013.788560

Zigler, S. J., Dewey, M. R., Knights, B. C., Runstrom, A. L., \& Steingraeber, M. T. (2004). Hydrologic and Hydraulic Factors Affecting Passage of Paddlefish through Dams in the Upper Mississippi River. 
bioRxiv preprint doi: https://doi.org/10.1101/2021.12.05.471259; this version posted December 6, 2021. The copyright holder for this preprint (which was not certified by peer review) is the author/funder, who has granted bioRxiv a license to display the preprint in perpetuity. It is made available under aCC-BY-NC-ND 4.0 International license. 
536 Table 1: Main characteristics of obstacles ('Lon': longitude; 'Lat': latitude; 'Height' (in m), 'Slope' and

537 presence of a 'fish pass'), details about mitigation measures (type and date of actions) and timelag (in 538 days) between mitigation measures and second sampling sessions.

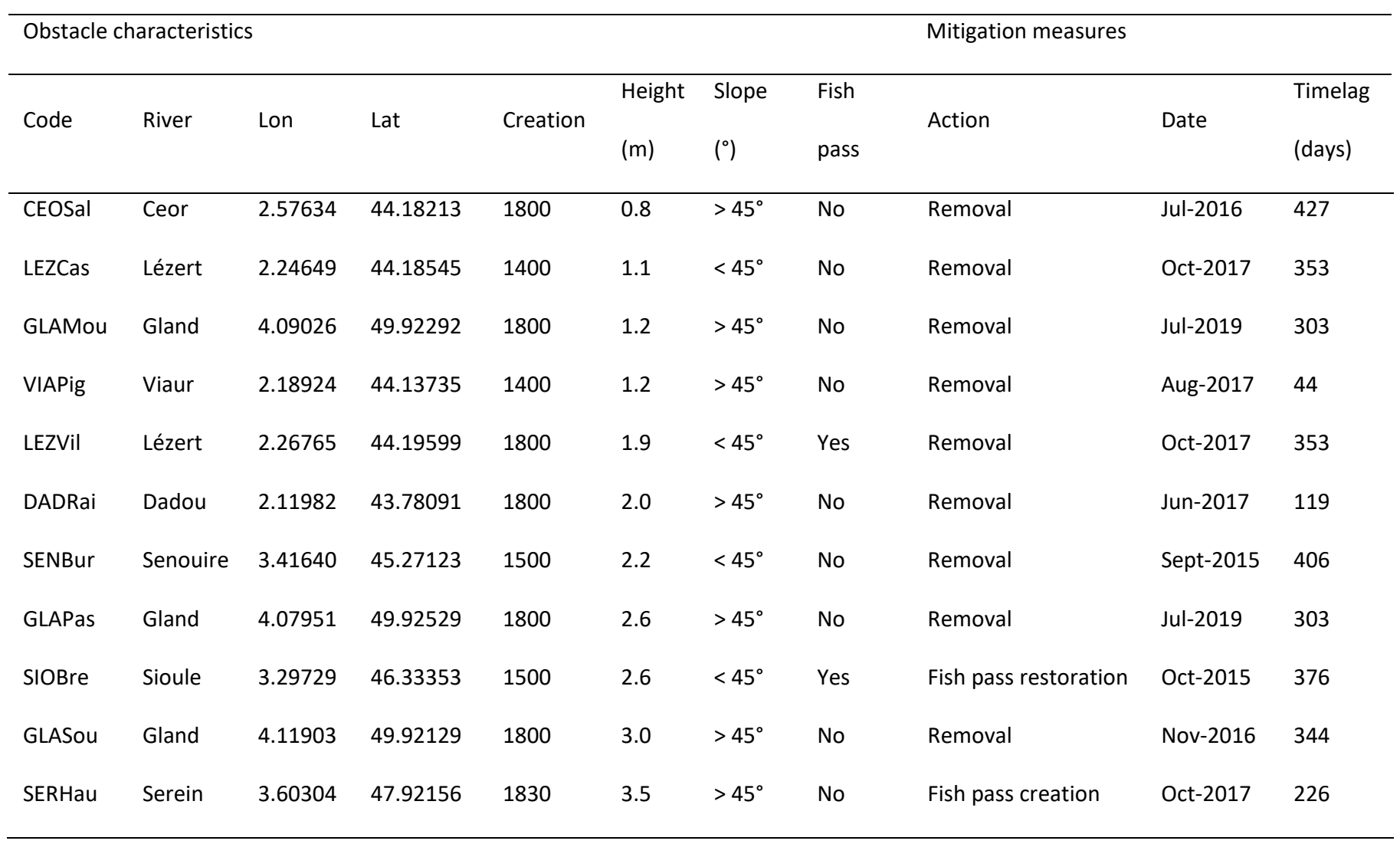

540

541 
543 Table 2: For each dataset (that is, a combination of one obstacle and one genus), observed effect sizes

544 of barrier effects $\left(\mathrm{F} \pm \mathrm{SD}_{\mathrm{F}}\right)$ both before and after restoration and observed effect sizes of restoration $(\Delta \mathrm{F} \pm$

$545 \mathrm{SE}_{\Delta}$ ), respectively. Note that $\mathrm{SD}_{\mathrm{F}}=2 \times \mathrm{SE}_{\mathrm{F}}$. Significant effect sizes (see Figure 2) are in bold and indicated

546 with a star. The last column 'Recovery' indicates whether the restoration action (Removal or Fish pass

547 creation) led to the partial or the full recovery of connectivity, when applicable.

\begin{tabular}{|c|c|c|c|c|c|c|c|c|c|c|c|c|}
\hline \multirow{3}{*}{$\begin{array}{l}\text { Obstacle } \\
\text { code }\end{array}$} & \multirow{3}{*}{ Genus } & \multicolumn{6}{|c|}{ Barrier effect } & \multirow{2}{*}{\multicolumn{2}{|c|}{ Restoration efficiency }} & \multirow[b]{3}{*}{$\mathrm{SE}_{\Delta}$} & & \multirow[b]{3}{*}{ Recovery } \\
\hline & & \multicolumn{2}{|c|}{ Before restoration } & \multicolumn{3}{|c|}{ After restoration } & & & & & & \\
\hline & & $\mathrm{F}$ & $\mathrm{SD}_{\mathrm{F}}$ & & $\mathrm{F}$ & $S D_{F}$ & & Action & $\Delta \mathrm{F}$ & & & \\
\hline \multirow[t]{2}{*}{ CEOSal } & Gudgeons & 0.00 & 0.00 & & 0.00 & 0.00 & & Removal & 0.00 & 0.00 & & / \\
\hline & Minnows & 64.42 & 1.59 & $*$ & 35.52 & 2.22 & $*$ & Removal & -28.91 & 1.37 & $*$ & Partial \\
\hline \multirow[t]{2}{*}{ LEZCas } & Gudgeons & 27.25 & 6.26 & $*$ & 0.00 & 0.00 & & Removal & -27.25 & 3.13 & $*$ & Full \\
\hline & Minnows & 0.00 & 0.00 & & 11.66 & 12.47 & & Removal & 11.66 & 6.23 & & / \\
\hline \multirow[t]{2}{*}{ GLAMou } & Gudgeons & 0.00 & 0.00 & & 0.00 & 0.00 & & Removal & 0.00 & 0.00 & & / \\
\hline & Minnows & 4.27 & 4.57 & & 0.00 & 0.00 & & Removal & -4.27 & 2.28 & & / \\
\hline \multirow[t]{2}{*}{ VIAPig } & Gudgeons & 32.48 & 0.99 & $*$ & 12.41 & 3.70 & & Removal & -20.07 & 1.91 & $*$ & Full \\
\hline & Minnows & 29.80 & 4.59 & $*$ & 8.35 & 8.93 & & Removal & -21.45 & 5.02 & $*$ & Full \\
\hline \multirow[t]{2}{*}{ LEZVil } & Gudgeons & 0.00 & 0.00 & & 10.39 & 11.14 & & Removal & 10.39 & 5.57 & & / \\
\hline & Minnows & 2.32 & 2.63 & & 0.00 & 0.00 & & Removal & -2.32 & 1.31 & & / \\
\hline DADRai & Gudgeons & 68.09 & 1.58 & $*$ & 26.82 & 1.20 & $*$ & Removal & -41.27 & 0.99 & $*$ & Partial \\
\hline \multirow[t]{2}{*}{ SENBur } & Gudgeons & 54.75 & 1.02 & $*$ & 48.22 & 1.87 & $*$ & Removal & -6.53 & 1.07 & $*$ & Partial \\
\hline & Minnows & 14.59 & 15.60 & & 0.00 & 0.00 & & Removal & -14.59 & 7.80 & $*$ & / \\
\hline \multirow[t]{2}{*}{ GLAPas } & Gudgeons & 55.42 & 2.24 & $*$ & 0.00 & 0.00 & & Removal & -55.42 & 1.12 & $*$ & Full \\
\hline & Minnows & 42.88 & 2.87 & $*$ & 0.00 & 0.00 & & Removal & -42.88 & 1.43 & $*$ & Full \\
\hline \multirow[t]{2}{*}{ SIOBre } & Gudgeons & 0.00 & 0.00 & & 0.00 & 0.00 & & Fish pass & 0.00 & 0.00 & & / \\
\hline & Minnows & 51.84 & 2.57 & $*$ & 39.46 & 1.61 & $*$ & Fish pass & -12.38 & 1.52 & $*$ & Partial \\
\hline GLASou & Minnows & 49.26 & 0.76 & $*$ & 32.51 & 4.77 & $*$ & Removal & -16.75 & 2.42 & $*$ & Partial \\
\hline \multirow[t]{2}{*}{ SERHau } & Gudgeons & 0.00 & 0.00 & & 0.00 & 0.00 & & Fish pass & 0.00 & 0.00 & & / \\
\hline & Minnows & 57.33 & 1.31 & $*$ & 49.10 & 2.05 & $*$ & Fish pass & -8.23 & 1.22 & $*$ & Partial \\
\hline
\end{tabular}


552 Table 3: Results of random meta-analyses for the overall effect sizes of fragmentation $\bar{F}$ and of

553 restoration $\overline{\Delta F}$. In presence of a moderator, EST is the estimate of the overall effect size for the

554 intercept (INT) and the deviation from the intercept for the alternate modalities, with the moderator as

555 a random effect. In absence of moderator (indicated with a slash), EST is the final estimate of the overall

556 effect size taking into account all sources of variation (including the previously identified significant

557 moderators as random effects, when applicable). Also provided are the number $n$ of datasets in each

558 modality, the standard error (SE) and $\mathrm{Cl}_{95 \%}$ (ci.low and ci.high) around EST, the Wald-Type $\mathrm{Z}$ statistic

559 (Zval) and the associated p-value (pval), and the QM test of moderator effect (QM statistic and

560 associated $p$-value).

\begin{tabular}{|c|c|c|c|c|c|c|c|c|c|c|c|c|}
\hline \multirow{2}{*}{$\begin{array}{l}\text { Overall } \\
\text { effect } \\
\text { size }\end{array}$} & \multirow[t]{2}{*}{ Random effects } & \multirow[t]{2}{*}{ Moderator } & \multirow{2}{*}{$\begin{array}{l}\text { Modalities } \\
\text { (INT = Intercept) }\end{array}$} & \multirow[t]{2}{*}{$\mathrm{n}$} & \multirow[t]{2}{*}{ EST } & \multirow[t]{2}{*}{ SE } & \multirow[t]{2}{*}{ ci.low } & \multirow[t]{2}{*}{ ci.high } & \multirow[t]{2}{*}{ Zval } & \multirow[t]{2}{*}{ pval } & \multicolumn{2}{|c|}{$\begin{array}{l}\text { Test of } \\
\text { moderator }\end{array}$} \\
\hline & & & & & & & & & & & QM & pval \\
\hline \multirow{7}{*}{$\bar{F}$} & Species|Dataset & Genus & Gudgeons (INT) & 5 & 47.72 & 7.63 & 32.77 & 62.67 & 6.25 & $<.0001$ & & \\
\hline & & & Minnows & 9 & -12.26 & 10.91 & -33.65 & 9.13 & -1.12 & 0.261 & 1.26 & 0.261 \\
\hline & Typology|Dataset & Typology & Low and gentle (INT) & 2 & 14.62 & 12.46 & -9.80 & 39.05 & 1.17 & 0.241 & & \\
\hline & & & Low and steep & 4 & 18.18 & 17.53 & -16.18 & 52.53 & 1.04 & 0.300 & & \\
\hline & & & High and gentle & 3 & 26.84 & 17.55 & -7.56 & 61.25 & 1.53 & 0.126 & & \\
\hline & & & High and steep & 5 & 40.00 & 13.15 & 14.22 & 65.78 & 3.04 & 0.002 & 11.45 & 0.010 \\
\hline & Typology|Dataset & & & 14 & 51.42 & 3.22 & 45.12 & 57.72 & 16.00 & $<.0001$ & & \\
\hline \multirow{9}{*}{$\overline{\Delta F}$} & Species|Dataset & Genus & Gudgeons (INT) & 5 & -30.14 & 8.50 & -46.80 & -13.47 & -3.54 & 0.000 & & \\
\hline & & & Minnows & 9 & 13.24 & 9.60 & -5.57 & 32.06 & 1.38 & 0.168 & 1.90 & 0.168 \\
\hline & Typology|Dataset & Typology & Low and Gentle (INT) & 2 & -14.62 & 12.46 & -39.05 & 9.80 & -1.17 & 0.241 & & \\
\hline & & & Low and Steep & 4 & -4.03 & 13.57 & -30.62 & 22.56 & -0.30 & 0.766 & & \\
\hline & & & High and Gentle & 3 & 4.81 & 12.73 & -20.13 & 29.75 & 0.38 & 0.705 & & \\
\hline & & & High and Steep & 5 & -18.32 & 15.25 & -48.22 & 11.57 & -1.20 & 0.230 & 7.79 & 0.051 \\
\hline & Timelag|Dataset & Timelag & $<1$ year (INT) & 10 & -24.04 & 5.67 & -35.16 & -12.92 & -4.24 & $<.0001$ & & \\
\hline & & & $>1$ year & 4 & 8.35 & 7.74 & -6.81 & 23.51 & 1.08 & 0.281 & 1.16 & 0.281 \\
\hline & 1|Dataset & & & 14 & -21.71 & 4.35 & -30.24 & -13.18 & -4.99 & $<.0001$ & & \\
\hline
\end{tabular}


bioRxiv preprint doi: https://doi.org/10.1101/2021.12 05.471259; this version posted December 6, 2021. The copyright holder for this preprint (which was not certified by peer review) is the author/funder, who has granted bioRxiv a license to display the preprint in perpetuity. It is made available under aCC-BY-NC-ND 4.0 International license.

\section{3 watersheds.}
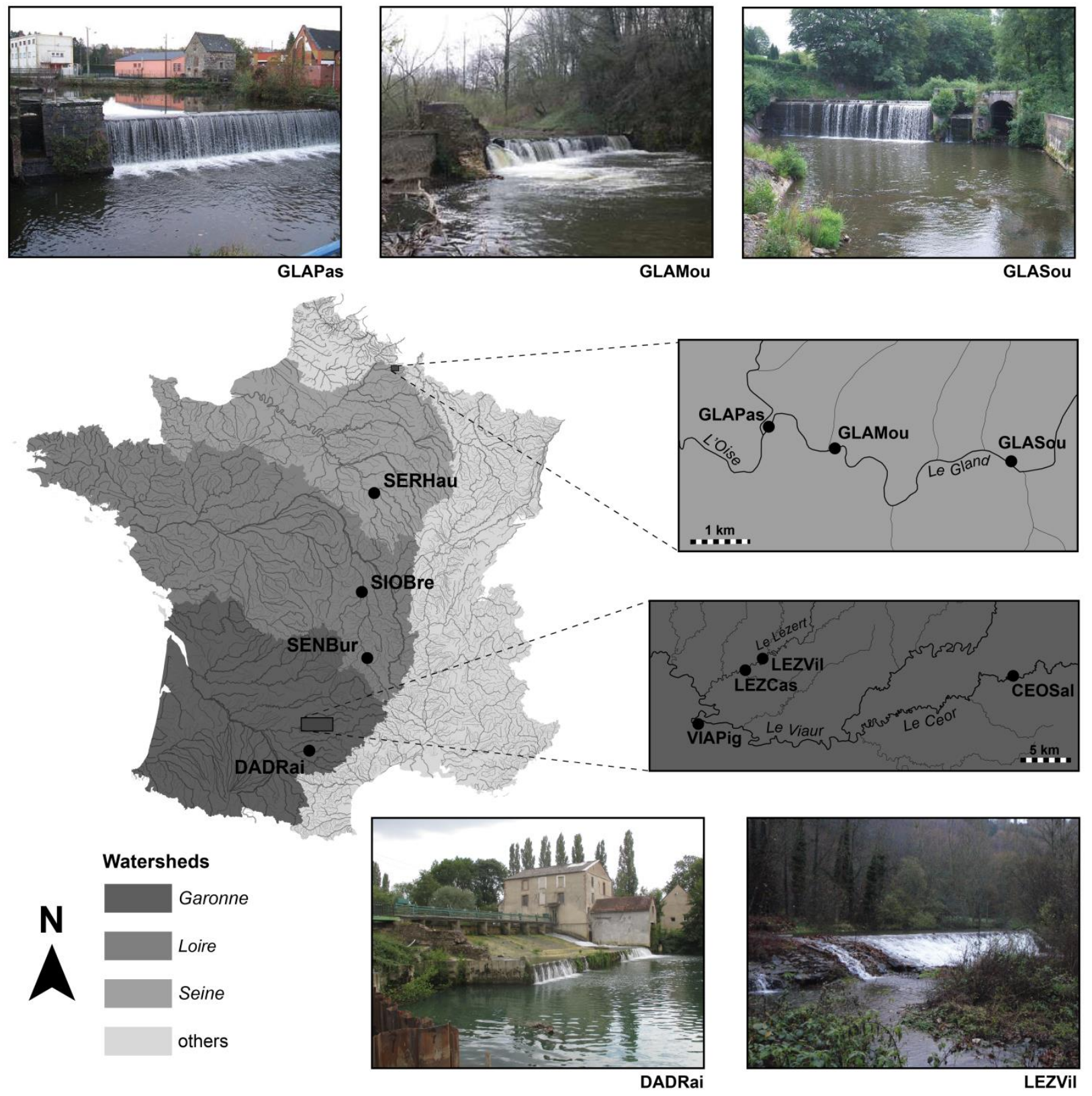

564 
Figure 2: Main results of the before-after genetic monitoring. For each obstacle (in columns), bars

567 represent FINDEx values with 95\% confidence intervals as computed before (in green) and after (in purple)

568 restoration in gudgeons (panel A) and minnows (panel B). Slashes indicate no data in both A and B.

569 Outlined bars represent significant barrier effects $\left(F_{\text {INDEX }}>20 \%\right)$. Green stars indicate a significant change

570 in FINDEX values after restoration (non-overlapping confidence intervals). Double purple stars indicate the

571 full recovery of connectivity following restoration (see details in Table 2). Panel C also provides few

572 details about obstacles (in green) and restoration (in purple) for direct comparisons with $\mathrm{F}_{\text {INDEX }}$ values

573 (see Table 1). Obstacles are sorted by their increasing height. Note that FINDEx values actually increased

574 after restoration in two datasets (LEZVil in gudgeons and LEZCas in minnows), but that new values were

575 lower than $20 \%$ and non-significantly different from 0 (and thus from FINDEx values before restoration)

576 according to $\mathrm{Cl}_{95 \%}$, a phenomenon owing to the stochasticity of genetic approaches 


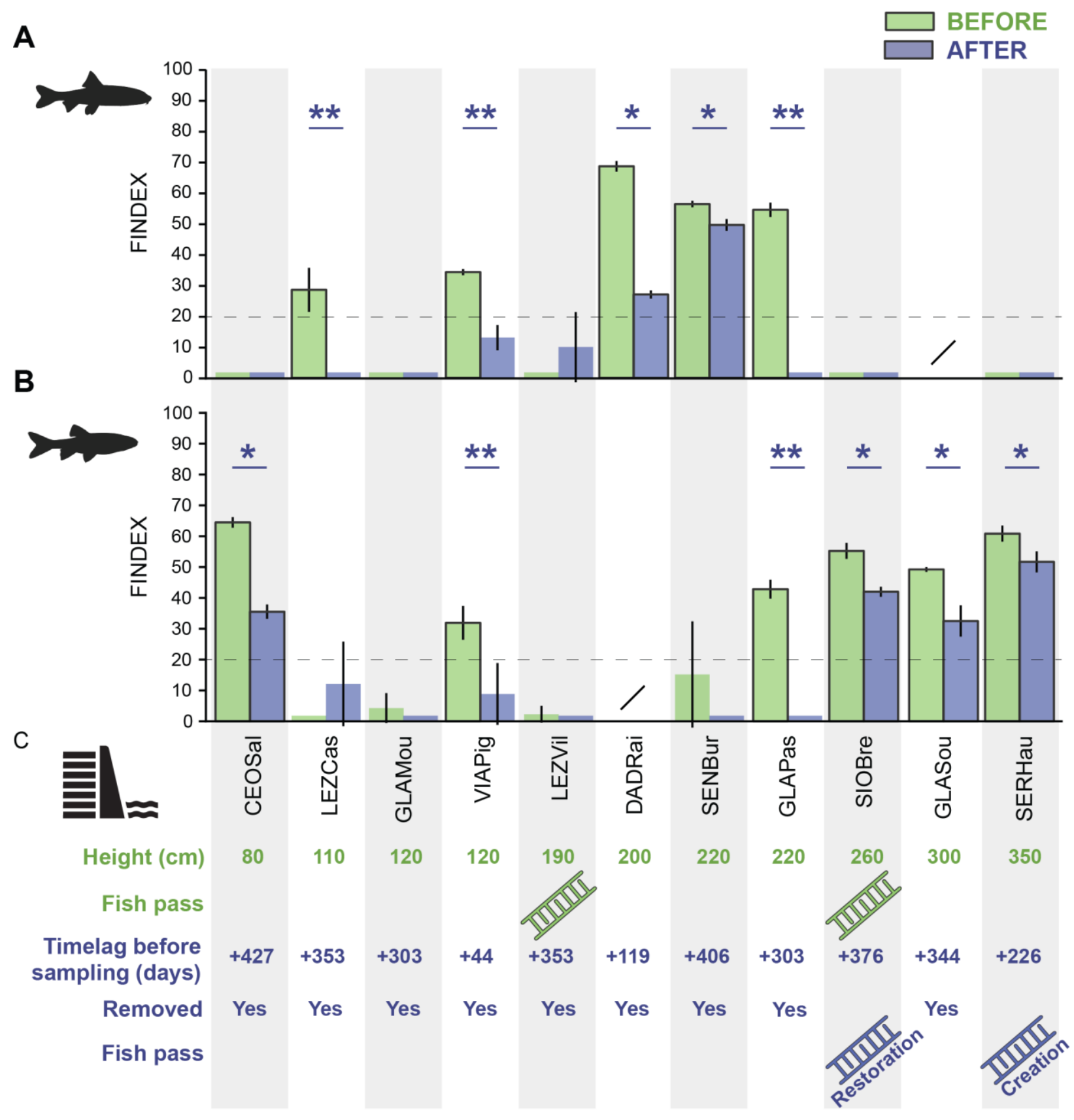


bioRxiv preprint doi: https://doi.org/10.1101/2021.12.05.471259; this version posted December 6, 2021. The copyright holder for this preprint (which was not certified by peer review) is the author/funder, who has granted bioRxiv a license to display the preprint in perpetuity. It is made available under aCC-BY-NC-ND 4.0 International license.

Figure 3: Overall effect sizes $\bar{F}$ of fragmentation for each modality of typology and overall true effect size

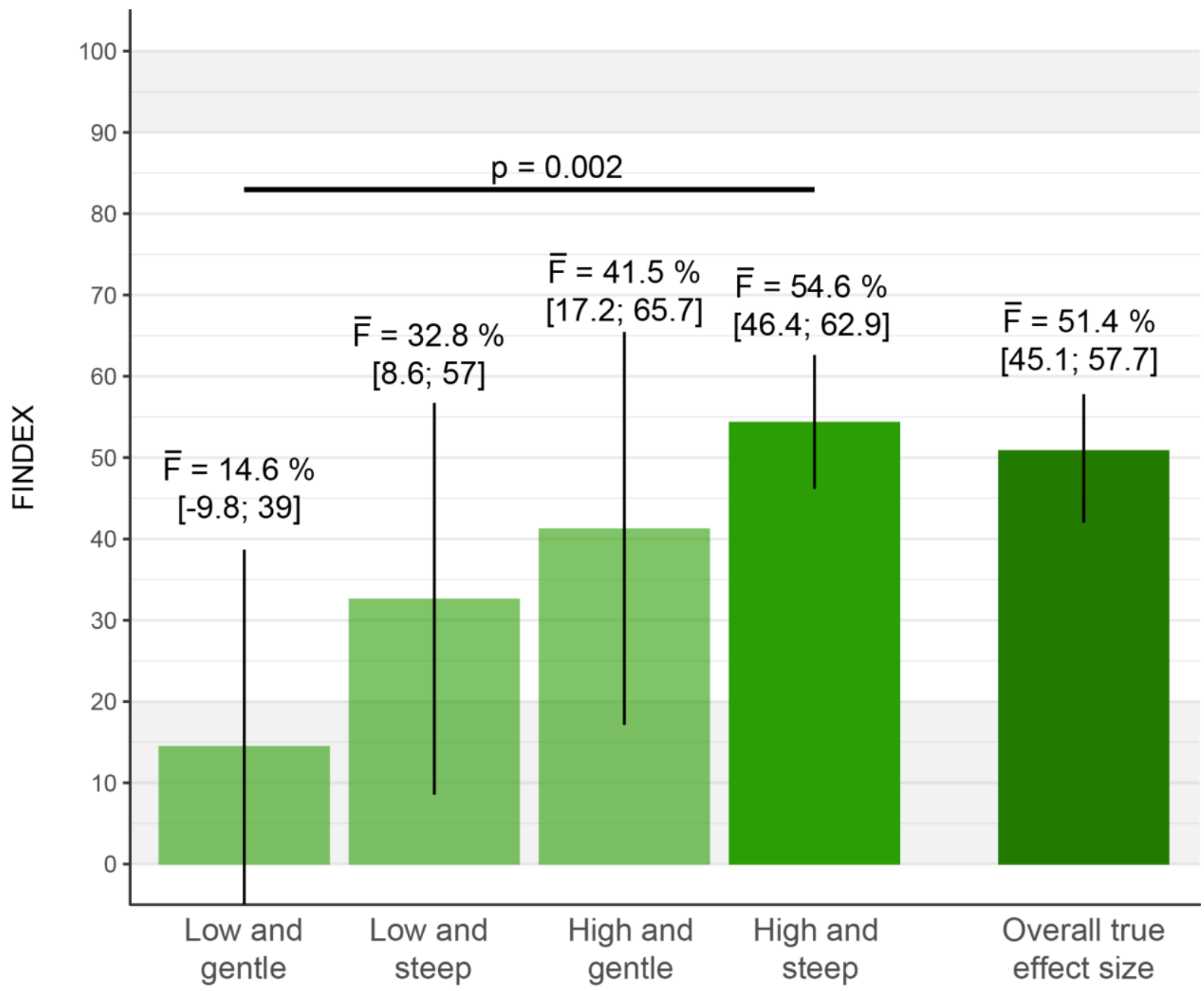


601 Genomic DNA was extracted using a salt-extraction protocol (Aljanabi \& Martinez, 1997). A subset of 15 602 and 19 autosomal microsatellite loci from Grenier et al. (2013) were amplified and genotyped in gudgeons 603 (BL1-153, Gob15, Gob16, Gob22, LC293, Lco4, MFW1, Ca1, CypG24, Gob12, Gob28, Lsou5, Rvla21177, 604 Smv03 and Lro12) and minnows (BL1-153, Ca3, CtoA-247, CtoG-075, CypG9, LSou8, LleA-071, LleB-072, 605 Ppro-132, Rru4, BL1-44, BL1-84, BL1-98, LC27, LceC1, LleC-090, Lsou5, MFW1 and Rhca20), respectively, 606 following PCR conditions described in Grenier et al. (2013).

607 Each combination of a genus, an obstacle and a sampling session ( $n=40$ ) was considered a unique 608 genotypic dataset, with corresponding genotypes coded in the genepop format (Rousset, 2008). For each 609 dataset, we assessed the presence of null alleles and checked for gametic disequilibrium using the null.all

610 function (R-package PopGenReport; Adamack \& Gruber, 2014) and the test_LD function (R-package 611 genepop; Rousset, 2008), respectively. Any locus showing significant gametic disequilibrium and/or

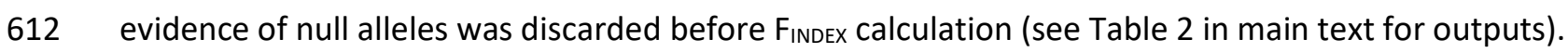


bioRxiv preprint doi: https://doi org/10.1101/2021.12.05.471259. this version posted December 6, 2021. The copyright holder for this preprint (which was not certified by peer review) is the author/funder, who has granted bioRxiv a license to display the preprint in perpetuity. It is made available under aCC-BY-NC-ND 4.0 International license.

615 The observed effect sizes of restoration $\Delta \mathrm{F}\left( \pm \mathrm{Cl}_{95 \%}\right)$ did not show any significant trend when increasing the

616 timelag between restoration and sampling.

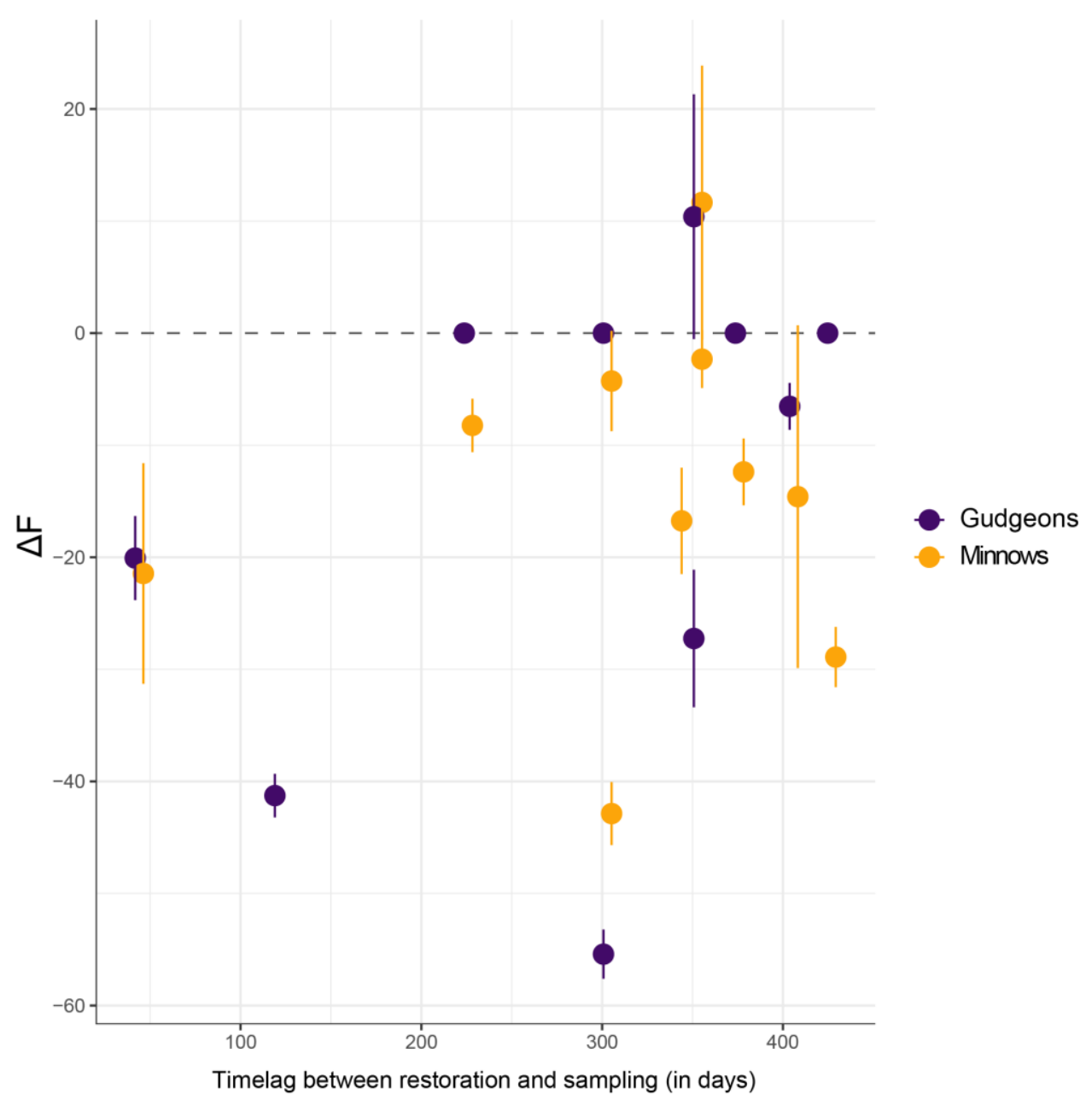

618 